\title{
THE IMPACT OF HRIS USAGE ON ORGANIZATIONAL EFFICIENCY AND EMPLOYEE PERFORMANCE: A RESEARCH IN INDUSTRIAL AND BANKING SECTOR IN ANKARA AND ISTANBUL CITIES
}

\author{
ILHAMI KAYGUSUZ, TAHIR AKGEMCI, ABDULLAH YILMAZ
}

\begin{abstract}
:
Organizations have to constantly monitor the changes around their internal and external environment in order to compete and maintain the business interests due to the pressure and brutal competitive conditions of technetronic age posed by globalization and Digital Revolution. The most important factor that can manage this change in the most efficient way is Strategic Human Resources Management, which is one of the human resources and key strategic management processes of the organizations. Information and qualified human resources and related information which are recognized as fundamental and strategic production factors for businesses and organizations in the Big Data age are obtained, produced, arranged, shared and used in strategic management processes through information technologies. The present study discusses factors such as growing importance of information and information management systems used to process such information, and its spreading usage in Human Resources Management and increasing efficiency of human resources management information in strategic management processes; and focuses on their impacts on management understanding and human resources management process in big data age. The impacts of emerging new conditions on Organizational Efficiency and Employee Performance are particularly investigated in terms of the usage of Human Resources Information Systems (HRIS). Survey method was used in the course of the research as a data collection method, and the sample consists of 160 senior managers, midlevel managers and employees from the industrial and banking sectors. The analyses conducted using correlation and regression test models showed that the Human Resources Management processes in businesses carried out through information systems contribute positively to organizational efficiency and hence to employee performance.
\end{abstract}

\section{Keywords:}

Information, Information Management, Management Information Systems (MIS), Human Resource Management (HRM), Human Resources Information System (HRIS), Organizational Efficiency, Employee Performance.

JEL Classification: M10

\section{Authors:}

ILHAMI KAYGUSUZ, HAVELSAN INC., Türkiye, Email: i_kaygusuz@havelsan.com.tr

TAHIR AKGEMCI, Faculty of Economics and Administrative Sciences, Selcuk University, Turkey, Turkey, Email: takgemci@selcuk.edu.tr ABDULLAH YILMAZ, Faculty of Economics and Administrative Sciences, Selcuk University, Turkey, 
Email: abdullahyilmaz@selcuk.edu.tr

\section{Citation:}

ILHAMI KAYGUSUZ, TAHIR AKGEMCI, ABDULLAH YILMAZ (2016). THE IMPACT OF HRIS USAGE ON ORGANIZATIONAL EFFICIENCY AND EMPLOYEE PERFORMANCE: A RESEARCH IN INDUSTRIAL AND BANKING SECTOR IN ANKARA AND ISTANBUL CITIES. International Journal of Business and Management, Vol. IV(4), pp. 14-52., 10.20472/BM.2016.4.4.002 


\section{INTRODUCTION}

Markets and economies are still remaining unstable with the impact of global financial crisis and regional developments that come up in the beginning of 2002, but technological compliance is ongoing and creating major and important changes in the organizations process. The global business in the new Digital Economy is critically influenced by four technological developments like Big Data, Cloud Computing, Internet of Things (IOT) and Social Media. These technological developments are forming the organizations and their Human Resources management. Thanks to the new technological developments of our age, industrial businesses prefer to utilize high-tech machine capacity rather than manpower capacity and resources in production, and they use robots. Information-intensive businesses are gradually replacing capital(machinery and equipment) and labor-intensive businesses. Efficient organization skill and management of information gained importance as defining and valuing the "information" come to the fore as opposed to labor, machinery and raw materials which play significant roles in the context of conventional capital. This has attributed value to the concept of "information management" which involves all actions such as creation, organization and efficient use of information as opposed to the management of intellectual capital (Cakar et al. 2010: 72).

The notion of management gains a new dimension in the cybereconosphere of this fourth digital revolution period in which we began to experience information age with an attention to electronic commerce, e-Government, Internet of Things (IoT), Big Data and Cloud Computing, and one of the success criteria of organizations in materializing their competitive strategies appears to be having well-equipped and qualified human resources of the internet and information age, and using these resources effectively and efficiently. Organizations need an effective Management Information System (MIS) compliant with business processes and human resources in particular, for a rapid and timely performance of decision-making, planning, structuring (organizing) and supervision operations by the managers. MIS' interface with human resources is the subsystem Human Resources Information System (HRIS). This is a system established for a regular acquisition, storage and processing of the information related with the employees and business processes, and sharing the resulting outcomes with managers and employees. Information and communication technologies are intensively utilized in composition of such systems. The effectiveness of this system depends, apart from the effective use by managers and employees through suitable software and hardware, on the degree by which the system conveys the information interpreted with metainformation to the decision-making organs rapidly, articulately, fully, accurately and uninterruptedly.

Although employees' awareness that they are monitored by information-based decision support systems in the work-related processes carries particular importance in terms of their improvement and success, it also brings along some drawbacks. Employees' feeling that they are being assessed by an independent and objective 
system and their trust in such a system would enhance their organizational commitment and diligence towards the work.

In the cybereconosphere (Cyberia) of today's information age, information and qualified intellectual capital information, as an important part of information, constitute a strategic and significant resource for the businesses. In particular, rapidly shortening product life curves and developing technology have increased the importance of the human element that seeks and finds information and commits it to production in an effective way. In this regard, the term worker in information age which is also called digital revolution wave has been referred to as "information worker" in the new terminology, and some management scientists began to adopt the use of the term netizen instead of citizen.

In the cybereconosphere of internet and information age, businesses on one hand work on organizational efficiency and productivity while on the other hand they struggle to achieve an important strategic goal such as keeping under control employee performance which they will employ and carry on using efficiently. In this sense, a large majority of the medium and large scale businesses in our country have Human Resources Management System (HRIS) compliant with Management Information System (MIS), which allows its use on different structures and levels according to the structure and strategic management understanding of the business. Intensive use of information technologies in the businesses has further increased the importance of human resources function in strategic decision-making processes, and this unfolded the requirement of conducting a right planning and design for aligning information technologies with business management functions and employees' competency in technology use.

In the scope of the study, theoretical information is provided on the type of information required for Human Resources Information System database, and the study mainly attempts to identify the degree of relationship between HR operations via information systems and performance appraisal and organizational efficiency in businesses taking into account the impacts of HRIS on employee performance and organizational efficiency. More precisely, the main objective of this research is to explore the impact of the usage of human resources information systems on organization effectiveness/efficiency and employee performance which influence organizational performance.

\section{THEORETICAL FRAMEWORK}

\subsection{The Concept of HRM and Its Scope}

Since the period of classical management understanding till information age, human resources and their management have been one of the fundamental and indispensable resources and strategic operation elements of organizations which they had to use to reach their goals and to be supracompetitive. The concept includes all employees from the top management to the lowest level employees, as well as involving the potential labor available in the external environment of the organization (Ogut et al. 2004: 278). 
Legal arrangements made by countries in HRM based on international dimension of HRM bound to certain rules by "International Labor Organization" (ILO) lays down human resources policies in public or private sector. The first practical actions regarding HRM were taken in 1940s with the keeping of the personnel-related records. In 1970s, the dimensions of the process were extended, and personnel management level reached midlevel management, and was sufficient enough to regulate and control working relations. By 1980s, the concept of human resources management was introduced, and it became more apparent in organizations' strategic decision-making processes, and affected top management and their decisions. Such a development can be recognized as the evidence of the unstoppable commencement of future HR process which includes several sub-processes such as selection and placement (recruitment), planning of work processes, performance appraisal (supervision), training and development, and retirement in lieu of a personnel management procedure where only the records are kept (Tortop et al. 2010: 16-17).

In the $21^{\text {st }}$ century, this change appears in two dimensions. The first refers to constant self-renewal of the technology used in the management of businesses, and social and organizational adaptation to this. The second dimension is more significant, and refers to change and relevant process of the human and organization in physical and psychomotor fields (Bayraktaroglu, 2011: 272-273).

Today's HRM practices are considered as a management understanding which renders organization's other processes more functional, and boosts efficiency and profitability more through qualified labor, and proves effective in achieving competitive advantage, and affects organization's prestige and success in the internal and external environment. HRM is a process which involves effective use of human resources in actualization of organization's strategic goals and meeting individual needs of the employees (Bingol, 2010: 3).

As a natural consequence of the political, economic, social, cross-border and overseas relations effective in our times, HRM means putting into practice all support activities for recruitment, placement, training and improvement of personnel working in managerial or operational positions and enhancing their efficiency being open to any innovations, changes and developments. Four basic functions included in this definition can be discussed under following headings: Staffing, Training and Development, Motivation, and Protection. The matters covered by these basic functions of HRM can be summarized as recruitment, employee's adherence to the organizational goals, and communication, motivation, performance appraisal, wage and social benefits, and training and improvement, work analysis, supply and planning of human resources, and quitting the job (Sabuncuoglu, 2000: 4-10).

HRM is established on two significant philosophy based on the foregoing functions. First is to increase the efficiency of employees by using their knowledge, skills and competencies reasonably for the goals of the business. The second is to meet the needs of the employees and encourage them for the work by contributing to their improvement and thus create job satisfaction. Human resources management uses human 
resources, and deals with basic functions of motivation and protection in order to achieve these two goals together (Ozgen et al. 2002: 8-9).

Universally, there are four basic universal goals for HRM. These goals offer a compass function for a safe navigation of the human resources function in organizations. These are social, organizational, functional and personal goals (Bayraktaroglu, 2011: 9).

Improving human capital and their digital and information technology skills through training and talent continues to be a benchmark of the production capacity in the $21^{\text {st }}$ century. Creative skill would provide a positive effect not only on the creative industries but also on all other sector capacities in order for them to accommodate future challenges. Creative and digital skills would in time create more innovative labor for the industry and service organizations. In this new period, managers have largely adopted the strategic perspective that the most significant determinants of organizational efficiency and productivity are human resources equipped with contemporary knowledge, skills and talents, and the skill to manage such resources (Ogut, 2012: 6869).

The management which distributes the resources so as to allow organizations reach their strategic goals can do so through employee recruitment methods compliant with information age, and strategic human resources management (SHRM) which would increase the efficiency of their information workers (Simsek and Oge, 2015: 34-35).

Strategic human resources management (SHRM) can be defined as a body of operations that occurred when the positive and negative differentiation in internal skills and capacity and external opportunities and threats, which affect organization's reason for existence and their being supracompetitive, influenced or determined human resources strategy and operations. In a HRM process characterized by such traits, such a positive and negative differentiation in organization's internal and external environment must be principally included and integrated into each of the strategic human resources, strategic planning and strategic actualization processes. Thus, it is extremely significant to ensure the harmony between an organization's external HR strategy elements and competitive environment, its strategy used in extraordinary conditions and general business strategy (Bayraktaroglu, 2001: 449-450).

\subsection{Information Management, MIS and HRIS}

Recent developments in technology have made it possible to have a real-time, information-based and self-serving interactive work environment (Boateng, 2007: 23). The developments went even further, and resulted in 800000 petabyte data circulating around the world today. These developments show that information is now a part of organization capital with concepts like big data, cloud computing and internet of things (IOT), and define the dynamics of information economy which is heavily discussed in the recent times. The information which is predicted to reach 35 zettabytes in 2020 highlights its strategic importance and power as a potential future capital investment and most valuable asset of firms. Organizations try to shape their information management works around this strategy. With this perspective, they consider 
customers, employees and organizational structure as a form of capital (Sagsan, 2002: 16).

Information management is defined as three basic information operations: acquisition, storage and transfer (Clarke and Cooper, 2000: 8). Basically, information management is an integrated and systematic approach associated with determining, managing and sharing all information assets including labor's common knowledge and skills with a view to reaching organization's very special goals. The goal of information management is to manage the information which is crucial and useful for the organization. Organizational efficiency begins to increase when the right information reaches the right place at the right time (Plunkett, 2001: 7).

The computational environments where acquired data are compiled, organized, systemized, shared and integrated according to needs are called "information systems". Information systems are used in organizations for information management, and they are addressed in terms of three systems, namely Operational Process Systems (OPS), Management Information Systems (MIS) and Expert Systems. MIS has subsystems such as Decision Support Systems (DDS) and Human Resources Information System (HRIS). MIS which transforms the raw data from within and outside of the organization to formatted and structured useful information plays a more effective and important role in decision support process by conveying such to DDS subsystem for a solution to complicated management problems and more effective and efficient decision-making (Nowduri, 2011: 2). Therefore, MIS is defined as an integrated system supporting an effective decision-making process or providing the information required for supervision of organizational operations. In another definition, management information systems can be described as computer-based information systems which can join data from various sources in order to provide the information required for managerial decision (Gokcen, 2007: 40). Recently, MIS automation has been increasingly used. These automatic systems have yielded significant positive transformation and change in managerial decision-making of the organizations (Nowduri, 2011:3)

HRIS, as a subsystem of MIS, is an information system approach organized for measuring and assessing current human resources operations with regard to production (outcomes) in the post-industrial age. HRM's becoming gradually more complex and data-intensive in its use in execution of all operations, and in decisionmaking and planning for such operations has brought HRIS to the fore, and this system has helped HR managers and professionals to take more rapid, accurate and effective feedbacks and decisions (Bingol, 2010: 639).

Figure 1 shows HRIS' three subsystems and the data flow in management information systems. 
Figure 1. Human Resources Information System Data Flow Diagram

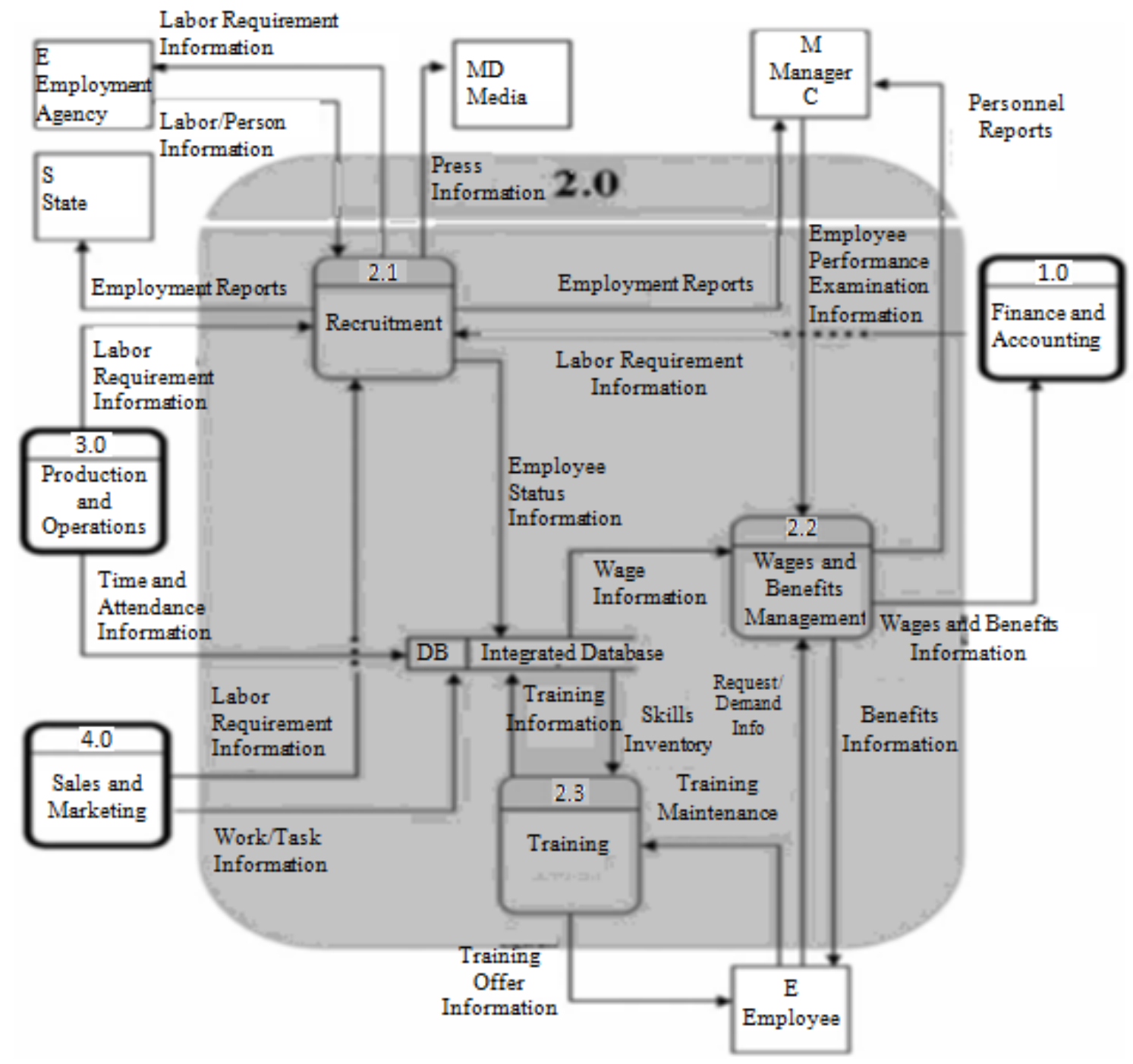

Source: GOKCEN, Hadi, "Yönetim Bilgi Sistemleri (Management Information Systems)", Palme Publishing, Ankara, 2007, p.297.

HRIS principally keeps the data related with the employees. System (2.0) is composed of three logical subsystems: HR planning and recruitment subsystem (2.1) which 
includes labor requirements and current labor information, and wages and benefits management subsystem (2.2) which includes employee's salary history, payroll practice, health and insurance information, performance payments and sales commissions, and training subsystem (2.3) which tracks career development with the inclusion of special skills and competencies in addition to the data on employees' performance appraisal, skills and talents (Gokcen, 2007: 295-296).

HRIS is a process allowing a business to gather, store, preserve, update and analyze the data, and prepare associated reports it requires in connection with its own human resources, personnel activities and organizational departments and their features (Celik and Akgemci, 2015: 165).

Besides, HRM can facilitate transition from active and reactive managerial functions to proactive strategic business partnership role by structuring HRIS technology in compliance with the organization culture and using it in a consistent way. HRIS' interactions with business' internal and external environment on the basis of managerial functions and proactive strategic business partnership are demonstrated in Figure 2.

Figure 2. Human Resources Management Information Systems and their Interactions

GENERAL EXTERNAL ENVIRONMENT

- Social

- Political

- Legal

- Cultural

- Technological

EXTRA-ORGANIZATIONAL INFORMATION SYSTEMS

- Insurance Companies IS

- Tax Institutions IS

- Social Security Institutions
OTHER IN-HOUSE

INFORMATION SYSTEMS

- Accounting Information Systems

- Management Information Systems

- Decision Support Systems

- Marketing Information Systems

STRATEGIC MANAGEMENT PROCESS

- Mergers/Participations

- Growth/Isolation

- Products and Servicing

Source: From Ogut, A. Bilgi Çağında Yönetim, Nobel Publishing, Ankara, 2012, p.75, adapted from M. J. Kavanagh, H.G. Gueutal, S. I. Tannenbaum, (1990), Human Resources Information System: Development and Application, PWS Kent: Boston MA, p.31. 
With increased use of HRIS, the job of Human Resources professionals has become easier, and thus they had opportunity to spare more time on in-house consulting activities. With a further approach, it is argued that human resources management professionals add value to the organizations while at the same time strengthening their influence and status in the organization (Lawler and Morhman, 2003: 2-6).

In order for HRIS to be successful, it must provide managers and users required and sufficient information in various stages such as keeping, planning, controlling and managing the data related with human resources (Dessler, 2005: 23).

Such information supplied by Human Resources Information System must bear specific features such as updatability, coming from right source through right methods, completeness and accuracy, and being analyzed and rapidly submitted to the users through right methods suitably for the purpose. Where no update is made, the managerial decisions to be taken will not be sound (Bingol, 2010: 645).

Sergio et al. (2010) believe that when HR functions are loaded into computers within a HRIS, more rapid decision-making is achieved in development, planning and management of HR thanks to much easier storing, updating, classifying and analyzing of the data (Sergio et al. 2010: 48-49).

One of the major benefits offered by HRIS is its contribution to the efficiency of control functions. Furthermore, it brings strategic benefits to the information sharing, creation of an organizational memory, increased speed of decision-making and establishment of a culture of commonality (Karcioglu and Ozturk, 2009: 363 ). Additionally, some other contributions yielded by the use of HRIS by businesses in their HRM operations can be counted as saving stationary expenses and costs of searching a job applicant, and risk management, financial planning, position control (personnel requirement), attendance reports and their analysis, and personnel planning, promotion planning, accident reporting and prevention, and hazardous material disclosure reports (Akman, 2010: 43).

\subsection{Organizational Efficiency and HRIS}

The current literature on HRIS shows that these systems have varying impacts on HR across organizations but offers little explanation about the variety. It proposes that HRIS is prevailingly used to automatize the routine tasks and "replace file cabinets" (Beadles, 2005: 39-40).

Khera and Gulati (2012) argued that several authors stated in their studies that HRIS is increasingly used in strategic decision-making process of the HR (Khera and Gulati, 2012: 7-8). Yet, the level of strategic HRIS use across organizations varies, and most of the organizations simply continue to use HRIS to remove manually-managed processes and to cut down on costs (Kristine et al. 2006: 3).

In practice, as long as the institutions are not convinced about the benefits offered by HRIS, they hesitate to practically use this system (Rangriz et al. 2001: 82). Advanced 
accuracy, timely and rapid access to information, and cost-saving are some of the most common benefits of HRIS (Sadiq et al. 2012: 80).

In a similar study, Teotia (2012) proposed five reasons justifying why organizations should use HRIS. These reasons relate to HRIS' contribution to organizations in following matters (Teotia, 2012: 229-239):

1. Enhancing competitiveness through developing and increasing HR operations,

2. Producing more comprehensive HRM reports,

3. Shifting HRM's role to Strategic Human Resources Management (SHRM),

4. Redesigning the whole HRM department of the organization,

5. The opportunity to use HRIS in supporting strategic decision-making operation, program and policy assessment or daily operational matters.

HRIS has become a basic instrument in enhancing organizational performance and effectiveness, and its purpose has become more holistic and complicated with the recent developments in information and technology (Sergio et al. 2010: 48).

Efficiency is described as an organization's degree to achieve its goals, and is a determining criterion used to identify how much an organization comes closer to the specified goal by using at a certain extent and efficiency the inputs such as workmanship, raw materials, materials, information and employees in the course of the goals. In other words, it is the measurement of the rate of achievement of the performance criteria set forth in the strategic plan. Efficiency function can be formulized through the equations below (Simsek and Celik, 2015: 135):

\section{Efficiency $=$ Achieved Status/Goal x 100}

\section{Efficiency = Standard Performance (Value)/Achieved Performance}

With the use of "system approach" in scientific practices, different dimensions of management came to be subject matters of implementation. One of such different dimensions is efficiency. Gibson et al. argues that there is a relationship between management, organization and efficiency, and such a relationship should be defined in three different perspectives, and an effective personal, group and organizational performance is an outcome of efficient planning, organization, leader and control. This is not such an easy procedure for the institutions and organizations. Managing people with different cultural structures, and achieving individual and group goals and organizational efficiency is a challenging, annoying but rewarding task for organizations in a rapidly-changing and complicated environment (Gibson et al. 1991: 25).

Ekinci and Yilmaz (2002) put forward that individual and group efficiency jointly creates the organizational efficiency, and thus the efficiency can be discussed as follows in two significant managerial fields as organizational and managerial efficiency (Ekinci and Yilmaz 2002: 36-38):

- $\quad$ "Managerial efficiency" which supports planning and implementation of basic managerial processes in an organization such as decision-making, technology selection and organizational reporting (Henry et al. 1993: 62) 
- "Organizational efficiency" is a flexible structure which allows easy interaction and helps employees to establish relations with the institution and among themselves more easily and thus yield more productivity and work performance.

The emergence of new technologies and communication tools which facilitate establishment of networks beyond cultural and geographical boundaries has necessitated changes in organizational models and working methods that would bring about organizational success, efficiency, performance and strategic competitive advantage. It is noted that the studies in the field of organizational efficiency, during the period from early 1970 s to our day, have focused on around 30 different criteria which would help in measuring the organizational transformation and success on the grounds of organization efficiency under the influence of new technologies, communications tools and market conditions. These criteria are indicated below (Duygulu, 2003; Akalin, 1992: 9-10):

1- Total Efficiency, 2- Productivity, 3-Profit and Social Benefit, 4- Quality and Compliance with Work, 5- Work Health, Safety and Accidents, 6- Growth, 7- Excessive Absenteeism, 8- Employee Replacement Rate, 9- Job Satisfaction, 10- Motivation, 11Morale, 12- Supervision, 13- Conflict-Loyalty, 14- Flexibility-Harmony, 15- Planning and Goal Setting, 16- Goal Congruence, 17- Determination of Organizational Goals, 18Suitability of Roles and Norms, 19- Managers' Mastery in Interpersonal Relations, 20Managers' Mastery at Work, 21- Information Management, 22- Organizational Communication, 23- Readiness, 24- Use of Environment, 25- Evaluation of Those Outside the Organization, 26- Equilibrium, 27- Value of Human Resources, 28Participation and Sharing of Authority, 29- Degree of Importance attached to Training and Improvement, 30- Valuing Success.

Nevertheless, the impacts of some these on organizational success are greater and more significant than others. It would be noteworthy to explain some criteria which are considered important (Duygulu, 2003):

- Productivity,

- $\quad$ Profit and Social Benefit,

- Quality (Suitable skills) is defined as the condition where organizational structure and human resources are compliant with organizational goals and have sufficient service skills.

- Growth is the increase in production capacity, personnel number, sales, profits and investment rates,

- Job Satisfaction,

- Motivation,

- Value of Human Resources,

- Degree of Importance attached to Training and Improvement,

- Valuing Success.

Looking into a large number of studies conducted recently on organizational efficiency and performance, it appears that there are several factors such as information 
management and HRM that influence these variables. Fugate et al. (2009) investigated the impact of information management processes on business and organizational performance with regard to logistic process, and demonstrated a significant positive relationship between information management processes and business and organizational performance (Fugate et al. 2009: 247-264).

Yeung et al. (2007) studied the impact of organizational learning and innovativeness on organizational performance, and found that a proper management of the information in the information-based economies of this age of information economy is important, and that a significant relationship exists between the variables organizational learning and innovativeness, and organizational performance, and that the basic sustainable strategic resource for a company in $21^{\text {st }}$ century is the skill to transform new discrete information and adapt it to the processes, and to transform itself into a constantly-learning organization (Yeung et al. 2007: 2459-2477).

McEvily and Chakravarthy (2002) argued that technological knowledge involved in the information-based organizational performance in the global market of information age and integration of the knowledge in organization's main production development process might contribute to organizational efficiency and competitive advantage (McEvily and Chakravarthy, 2002: 285-305).

Argote and Ingram (2000) suggested that an information and communication infrastructure facilitating the communication in the organization would make information sharing easier, and this quality enhances organizational learning and improves organizational performance (Argote and Ingram, 2000: 150-169).

Gold et al. (2001) argued that it is a challenging process to abruptly change conventional organizational structures with a long history, and that managers' unwillingness and information management in information-based organizations relate to the skill of managing information, and that information management infrastructure and information processing process are important, and that transformation to information-based organization structure would develop organizational skills and effectiveness (Gold et al. 2001: 185-214).

Bulbul (2007) concluded that businesses' "success of creating value" in digital economy of the information age depends on their relations with all employees, customers, suppliers and shareholders, and the "knowledge" they derive from these relations, and that the businesses which hold more information or succeed in preserving the information more would increase their market value, and that information-based organizational structure and information management are what businesses need in the long run in order to enhance their organizational efficiency and performance, as well as achieving a sustainable competitive advantage (Bulbul, 2007: 176-177).

Johnson and Guental (2011) believe that HRIS can prevent the costly error that occurs in the matter of social benefits, and save the organization from the resulting expenses (Johnson and Guental, 2011: 1-48). 
Wiblen, Grant and Dery (2010) argued that HRIS would decrease organizational costs through automation of the previous labor-intensive operations, and sustain and facilitate the communication from the lowest to the highest level of the organization, and be an instrument that increases efficiency (Wiblen et al. 2010: 251-267).

In this age when globalization is perceived as deregulation and becoming unrestricted, an organization structure including a human resources information system has become an active tool in establishing an easier relation between employees and the organization and among themselves, and information sharing, cooperation (team spirit), netizen culture and hence more productivity and more work performance. Sergio et al. (2010) believe that an effective HRIS is a must in today's organizations in order to tackle the issues such as increasing organizational demands, and more comprehensive use of information, and more extensive need for information, and the constant pressure for reducing the costs and making HR a more strategic business partner, and they argue that HRIS has become an essential tool in enhancing organizational performance and effectiveness (Sergio et al. 2010: 47-54).

HRIS is a solution to the problems of the organizations in order to provide costefficiency, and reduce managerial workload, and standardize HR processes or simply add strategic value to the decision-making action of the organization. There is consensus that among various practices HRIS is a very strong tool in boosting the effectiveness of an organization and hence its HR adequacy and organizational performance (Kumar and Parumasur, 2013: 569).

Brown (2008) attributed the efficiency of HRIS to its ability to give more effective and rapid results than the ones on paper. He warned that HRIS can be perceived as a necessary action for an organization but it may not result in more efficiency if it is not an effective tool for HR functions, and might on the contrary hinder efficiency (Brown, 2008).

A successful HRIS supports planning and implementation of basic managerial processes in an organization such as managerial decision-making, technology selection and organizational reporting structures. Therefore, HRIS has become an active tool in helping employees to establish relations with their organization and among themselves more easily and thereby yield more productivity and work performance (Beadles et al. 2005: 39-40).

\subsection{The Concept of Employee Performance and HRIS Impact}

The starting point of performance appraisal is clearly defining business processes and goals to be achieved in order for the employees to fully understand and comprehend what is expected from them in the organization. The factors affecting employee performance are primarily environmental conditions influencing a business' internal and external environment, and effective laws, union movements, organizational culture and performance appraisal system. These factors may have supporting or hindering effects towards employees' high motivation, performance and works (Bach, 2000: 254-258). 
In today's business world where competitive advantage rather than competition gained more importance and value, business organizations' achieving their strategic goals hinges upon the human resources they will employ and use efficiently. The organizations in the business world today have to operate in an intensive competitive environment that has never been matched. Being supracompetitive and different in such an environment is largely possible through fully utilizing the knowledge, skills and talents of the human resources of the business and ensuring their morale and motivation towards the work, or briefly using these resources effectively and efficiently. Human resources management comes into play right at this point, and plays an active role for showing how the employees can have higher performance and efficiency as well as a high morale, motivation, happiness and well-being so that the organizations can reach their goals and objectives compliant with their strategy "think globally, and act locally" (Simsek and Oge, 2015: 17).

Personnel Performance is personnel's contribution to the business goals. It shows how efficient the personnel discharge their duties and responsibilities. The person with a high performance is the one who has successfully discharged his duties and responsibilities, and his behaviors thereby contribute to the goals of the organization. The appraisal of the performance is measuring the contribution the personnel have made to the fulfillment of business goals (Aldemir et al. 2004: 291).

Throughout history, almost any organization aimed to have high success as a common goal. They have utilized business resources and especially human resources, though in varying rates and types, in attempting to achieve this goal. The most significant success criterion for human resources is the appraisal of performance (success). The method of appraising employee performance has varied in time, particularly depending on the size of the businesses. Failing to perform this appraisal as per universal scientific methods in small and medium-sized businesses leads to erroneous appraisal, and personal and organizational performance cannot be achieved (Yildiz et al. 2007: 239).

One of the major problems faced in businesses appear in employee performance appraisal. In this regard, it is crucial to identify to what degree the employees fulfill the works assigned to them or what skills and talents they have. According to Ivancevich, work performance appraisal is a function of the following three criteria (Ivancevich, 1990: 120):

- Capacity to perform: It requires employees to have skills, knowledge and experience suitable to the qualities of the job. It is impossible to expect high performance from an employee who does not have an idea about the method of work performance and what to do.

- Opportunity to perform: It is the equipment and environment required to perform a work. Where these requirements are not met, it would be still impossible to see a good employee performance. 
- Willingness to perform: As the third important factor, this relates to the condition where the employee has or does not have the willingness and desire required by the work assigned to him.

The significance of information workmanship is increasing with the emergence of information age business structures and the changing dimensions of competition where the change of everything at any time has become the norm and information is treated as an important and valuable resource in parallel with the resulting development of information and communication technologies. Businesses might be compelled to struggle to find, maintain and derive the highest performance from the qualified human resources from the labor market with qualities to show high performance and willingness to work. Businesses' offering an appealing working environment, and identifying employee performance appraisal objectively and efficiently through a transparent method by HRIS automation, and using promotion, wage and reward systems would contribute to the enhancing their performance (Yildiz et al. 2007: 239).

Bailey (1983) explained that HRIS use in HR would reduce the automation costs of the information and the number of employees but still contribute to employees' checking their own information, and would offer HRIS managers easy access to the relevant information and data, and allow them to conduct analysis and to make decisions and communicate with others without consulting to HR professionals (Ammarhusein, 2015: 11; Bailey, 1983: 530-546).

Although the ideal measurement of HRIS involves challenging measures such as return of investment (ROI), external variables render such a success measurement difficult, if not impossible. Thus, user satisfaction and perception for the system has often been used as a proxy measurement as a measure of the system effectiveness (Ammarhusein, 2015: 11-12; Haines and Petit, 1997).

Hussain et al. (2006) demonstrated in the study on HRIS Use and Impacts that there are some average differences in HRIS use in SMBs and large companies with regard to works for determining the scale of HRIS' use and utilization on strategic and operational level. Besides, they showed that although HR professionals are equipped with special HRIS use due to the professional strategic partnership, they had lower experience compared to individuals from other professions (Hussain et al. 2006: 75).

Dianna et al. (2006) demonstrated the impact of individual and e-HR system characteristics on four major performance variables (information flow, social interactions, perceived control and system recognition) in their study on effectiveness and recognition of Human Resources Systems and factors affecting these, and they offered a series of models (Dianna et al. 2006: 237).

\section{RESEARCH METHODOLOGY}

\subsection{Objective and Significance of the Research}

Information and communication technologies offer quick communication, information sharing, information access opportunities, career management, training and 
improvement, and creation of a more effective and efficient organizational structure by particularly constituting a competitive environment within and outside the business. Human resources lie at the center of this organizational structure. Human Resources Information System use which is compliant with Management Information System has spread in Human Resources Management process which has gone through an important and major change in the historical background of Strategic Management.

The main objective of this research is to investigate the impacts of Information and Communications Systems (HRIS) in Strategic Human Resources Management as one of the Basic Strategic management processes of the large and medium-size companies in Turkey and the most important asset and production factor of businesses in the Big Data age on organizational efficiency and employee performance, and to offer some solution recommendations.

The main question of the research is to find out the direction and degree of HRIS' impact on organizational efficiency and employee performance in various businesses which utilize HRIS as used in human resources management operations as one of the basic strategic processes of organizations and supporting employees' expectations such as recruitment, performance management, wage plan and its analysis, training, skill management and redundancy.

In line with this basic objective and question, following sub-goals were identified:

1. Finding whether HRIS in businesses bear HR functions, and their usage status.

2. Finding how efficiently the "performance appraisal" dimension as an important function of HRIS is implemented, and whether the implementation meets desired quality.

3. Finding the existence and direction of the relationship between HRIS usage and organizational efficiency and employee performance.

Figure 3 shows the Research Model developed for this purpose. 
Figure 3: Research Model



\subsection{Hypotheses}

In this context, following hypothesis shall be tested.

H1a: Organizational efficiency varies significantly depending on the use of human resources information systems in the business.

H1b: Employee performance varies significantly depending on the use of human resources information systems in the business.

H1c: Usage rate of human resources information systems in the business affects organizational efficiency.

H1d: Usage rate of human resources information systems in the business affects employee performance. 
H1e: While organizational efficiency being constant, usage rate of human resources information systems in the business affects employee performance.

H1f: Employee performance affects organizational efficiency.

\subsection{Research Method}

In line with the objective of the study, we measured the usage status and rate of human resources management system by businesses, and the employees were asked to evaluate the efficiency of the company and their own performance. With the subsequent suitable analysis techniques, we tested what kind of an impact the usage status and rates of human resources management system in the business have on the performance and efficiency of the business and employee performance. Moreover, we modularized organizational efficiency, and tested HRIS usage rate on employee performance. Apart from that, we also analyzed the relationship and impact between employee performance and business efficiency.

The independent variable in the study is usage rate of human resources management information system, while the dependent variables are organizational efficiency and employee performance. Furthermore, the model divides organizational efficiency and tests the impact of usage rate of HRIS on employee performance, where the independent variable is the usage rate of HRIS, and the dependent variable is employee performance, and the intervening variable is organizational efficiency.

\subsection{Information About the Data Collection Tool of the Research}

Questionnaire form was used in the study as a tool for data collection. Approximately 160 senior managers, midlevel managers and employees working in different sectors were administered the questionnaire form which consists of four sections. The first section includes personal information, and the second includes usage status of HRIS modules, and the third includes an evaluation of organizational efficiency and the fourth includes personal performance appraisal.

The scale on usage status of HRIS model which worked to obtain usage rate of HRIS was borrowed from the study titled "Factors Playing a Role in the Success of Human Resources Information Systems: A Research" conducted by Aras in 2012.

The scale on evaluation of organizational performance/ efficiency was borrowed from the study titled "The Relationship between Work Ethics Practices and Organizational Performance in Human Resources Management: The Case of Fortune's 500 Biggest Companies in Turkey" conducted by Bayraktaroglu and Yilmaz in 2012, and from the study titled "The Relationship between Information Management and Organizational Efficiency: Basic Principles of Organizational Culture and Organizational Structure" conducted by Cakar et al. in 2010, and from the study titled "The Impact of HRIS on Organizational Efficiency: Random or Integrated and Holistic" conducted by Kumar and Paramasur in 2013.

As the employee performance scale, 4-item employee performance scale which was first used by Kirkman and Rosen (1999) to measure employee performance and 
then by Sigler and Pearson (2000) in their studies and later adapted to Turkish by Col (2008) was used in order to measure the performance of the employees. Reliability coefficient and total variance explanatory percentage of the scale was 0,88 and 61,4 , respectively. The scale was also used in the study titled "The Impact of Organizational Climate on Employee Performance: A Research on Employees in Ostim Manufacturing Businesses" conducted by Tutar and Altinoz (2010). Moreover, we drew on the study titled "The Impact of HRM Practices and Organizational Culture on Employee Performance" conducted by Kaya and Kesen in 2014, and the one titled "The Relationship between Performance Appraisal and Human Resources Information Systems (HRIS) in Businesses - A Research in Istanbul province" conducted by Karcioglu and Ozturk in 2009.

\subsection{Research Population and Sample}

The research population covers the senior and midlevel employees of the companies operating in industrial and banking sectors, and the sample consist of employees randomly selected in this main population.

160 employees were randomly selected from the population as the sample, and the data were collected through the hand-delivered questionnaires.

\section{FINDINGS}

The data were analyzed using SPSS 21.0 software. The results of usage status of HRIS module were used in the analyses to obtain the usage rate of HRIS in the business. In testing the hypotheses, independent groups t test, correlation test and regression test were used.

T test was used to analyze whether organizational performance and employee performance varied significantly depending on the usage status of HRIS in the business. The impact of the usage rate of HRIS on organizational performance and employee performance, and the impact of employee performance on organizational performance were analyzed through regression analysis.

\subsection{Construct Validity and Reliability Analysis}

Exploratory factor analysis (EFA), and Cronbach's Alpha Reliability Coefficient were used to identify construct validity and reliability of the scale, respectively.

\subsection{Reliability Analysis}

Cronbach's Alpha value is the compliance value depending on the correlation between the questions or expressions. This value indicates reliability levels of the questions in scales. Where Cronbach's Alpha value is over 0,70 and even more, the scale is considered reliable (Sekeran, 2003: 311; Sipahi et al., 2008: 89). 
Table 1: Factor Analysis Results of Organizational Efficiency, Personal Performance and HRIS-oriented Personal Performance Scale

\begin{tabular}{|c|c|c|c|c|c|}
\hline Dimension & Question & Expressions & $\begin{array}{c}\text { Factor } \\
\text { Load }\end{array}$ & $\begin{array}{l}\text { Variance } \\
\text { Explained }\end{array}$ & $\begin{array}{l}\text { Cronbach's } \\
\text { Alpha }\end{array}$ \\
\hline \multirow{7}{*}{$\begin{array}{l}\text { Organizational } \\
\text { Efficiency }\end{array}$} & Organization.4 & $\begin{array}{l}\text { The training } \\
\text { opportunities for } \\
\text { the employees } \\
\text { in our company } \\
\text { have increased. }\end{array}$ & ,943 & \multirow{7}{*}{66,172} & \multirow{7}{*}{ 957 } \\
\hline & Organization.5 & $\begin{array}{l}\text { Our customers' } \\
\text { satisfaction with } \\
\text { our organization } \\
\text { has risen. }\end{array}$ & ,899 & & \\
\hline & Organization.9 & $\begin{array}{l}\text { Our labor } \\
\text { efficiency has } \\
\text { risen. }\end{array}$ & ,897 & & \\
\hline & Organization.3 & $\begin{array}{l}\text { Employees' } \\
\text { opportunity to } \\
\text { participate in the } \\
\text { management in } \\
\text { our company } \\
\text { has grown. }\end{array}$ & 883 & & \\
\hline & Organization.10 & $\begin{array}{l}\text { The profitability } \\
\text { of our sales has } \\
\text { increased. }\end{array}$ & ,877 & & \\
\hline & Organization.6 & $\begin{array}{l}\text { Our power to } \\
\text { attract new } \\
\text { customers to } \\
\text { our organization } \\
\text { has grown. }\end{array}$ & ,875 & & \\
\hline & Organization.11 & $\begin{array}{l}\text { Our } \\
\text { organization's } \\
\text { new product } \\
\text { development } \\
\text { attempts have } \\
\text { grown. }\end{array}$ & 863 & & \\
\hline
\end{tabular}




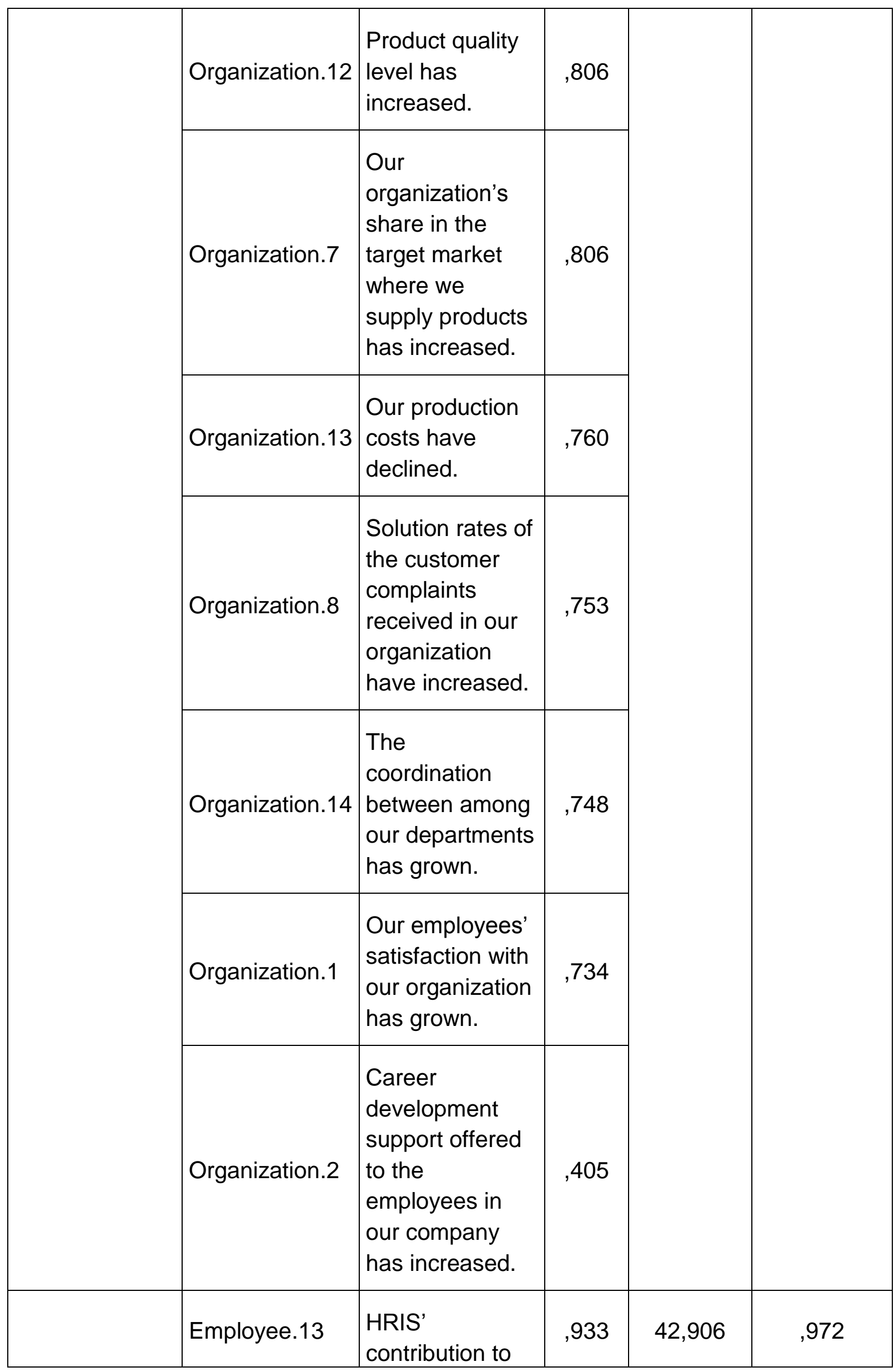




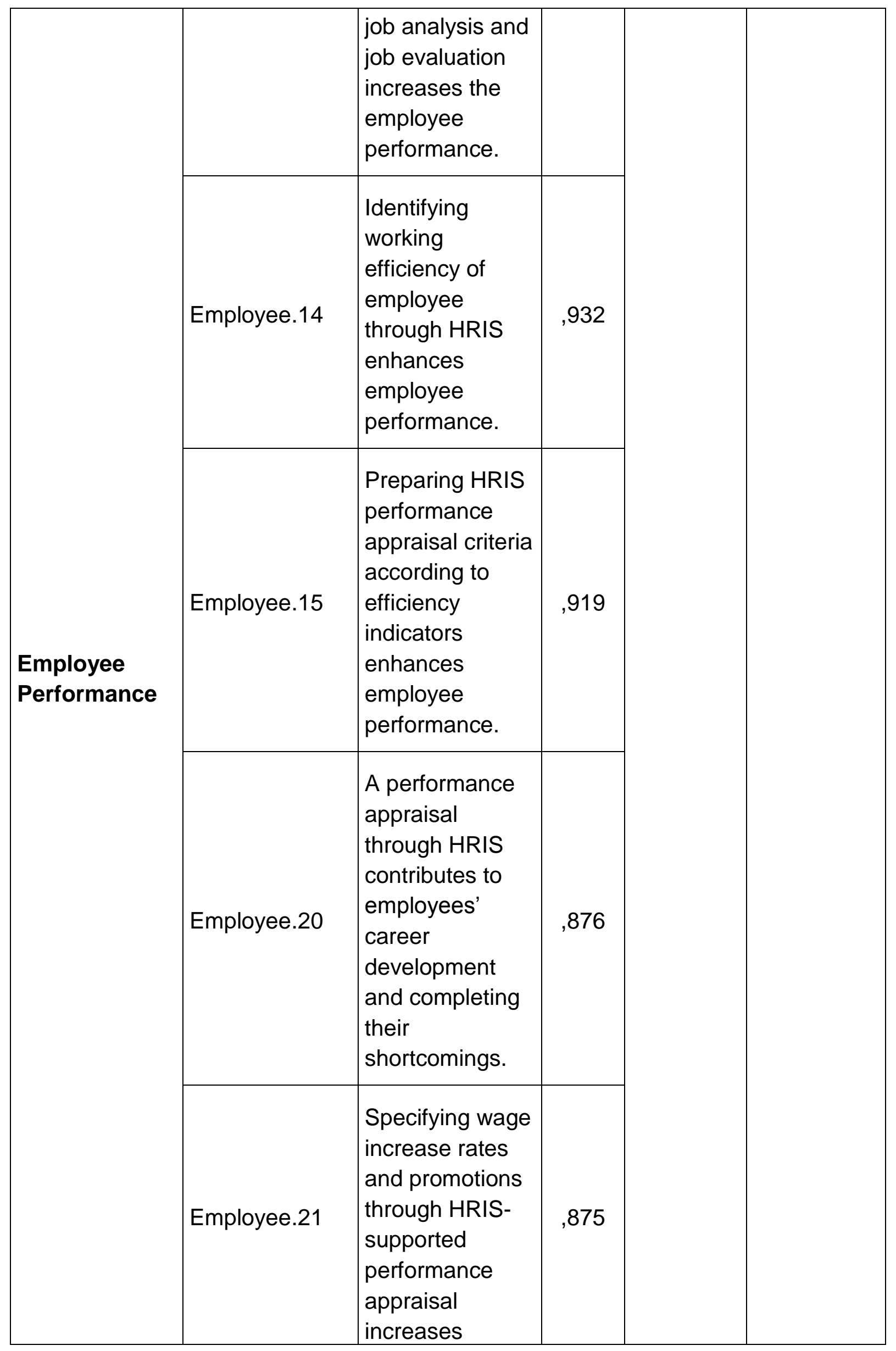




\begin{tabular}{|l|l|l|l|}
\hline & $\begin{array}{l}\text { employee } \\
\text { performance. }\end{array}$ & \\
\hline & Employee.19 & $\begin{array}{l}\text { Joining HRIS } \\
\text { practices } \\
\text { enhances } \\
\text { employee } \\
\text { performance. }\end{array}$ &, 851 \\
\hline \multirow{2}{*}{ Employee.18 } & $\begin{array}{l}\text { Conducting a } \\
\text { career planning } \\
\text { after a } \\
\text { performance } \\
\text { appraisal } \\
\text { through HRIS } \\
\text { enhances } \\
\text { employee } \\
\text { performance. }\end{array}$ &, 843 \\
\hline Employee.16 & $\begin{array}{l}\text { A performance } \\
\text { appraisal } \\
\text { through HRIS } \\
\text { covering the } \\
\text { dimension of } \\
\text { personal } \\
\text { features and } \\
\text { behaviors in } \\
\text { addition to } \\
\text { quality and } \\
\text { quantity of the } \\
\text { work enhances } \\
\text { employee } \\
\text { performance. }\end{array}$ & \\
\hline & $\begin{array}{l}\text { Following HRIS } \\
\text { performance } \\
\text { appraisal and } \\
\text { making } \\
\text { comparison } \\
\text { through HRIS } \\
\text { enhances } \\
\text { employee } \\
\text { performance. }\end{array}$ &, 687 \\
\hline & & \\
\hline
\end{tabular}




\begin{tabular}{|c|c|c|c|c|c|}
\hline \multirow{7}{*}{$\begin{array}{l}\text { HRIS-oriented } \\
\text { Employee } \\
\text { Performance }\end{array}$} & Employee.6 & $\begin{array}{l}\text { I contribute to } \\
\text { minimizing the } \\
\text { costs of } \\
\text { product/service } \\
\text { or delivery in my } \\
\text { company. }\end{array}$ & ,888 & \multirow{7}{*}{37,116} & \multirow{7}{*}{, 961} \\
\hline & Employee.2 & $\begin{array}{l}\text { The sense of } \\
\text { being } \\
\text { appreciated } \\
\text { while I perform } \\
\text { my work } \\
\text { influences my } \\
\text { performance. }\end{array}$ & ,860 & & \\
\hline & Employee.11 & $\begin{array}{l}\text { I try to develop } \\
\text { new ideas or } \\
\text { methods in my } \\
\text { job. }\end{array}$ & ,846 & & \\
\hline & Employee.3 & $\begin{array}{l}\text { The support and } \\
\text { guidance from } \\
\text { my superiors } \\
\text { influences my } \\
\text { performance. }\end{array}$ & ,841 & & \\
\hline & Employee.5 & $\begin{array}{l}\text { I contribute to } \\
\text { creation of } \\
\text { innovation in my } \\
\text { company. }\end{array}$ & ,826 & & \\
\hline & Employee.7 & $\begin{array}{l}\text { I contribute to } \\
\text { development of } \\
\text { new } \\
\text { product/service } \\
\text { and market } \\
\text { opportunities in } \\
\text { my company. }\end{array}$ & ,797 & & \\
\hline & Employee.8 & $\begin{array}{l}\text { I contribute to } \\
\text { organizational } \\
\text { efficiency and }\end{array}$ & ,785 & & \\
\hline
\end{tabular}




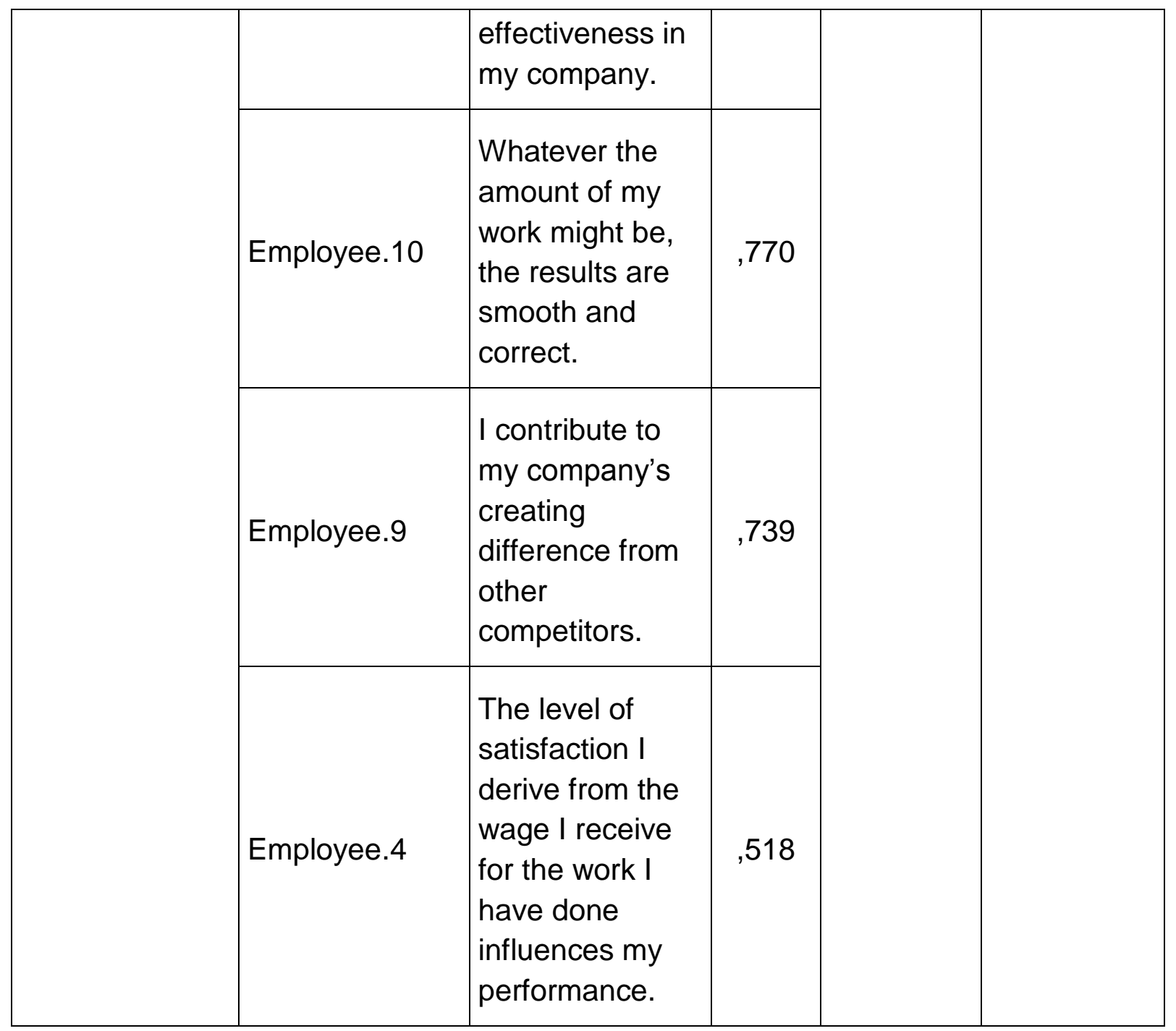

As a result of the factor analysis, the Organizational Efficiency scale consists of 14 items with factor loads ranging from 0,405 to 0,943 . The total variance explanatory percentage of the scale is 66,172 with a very high reliability level. Employee performance scale consists of 9 items with factor loads ranging from 0,687 to 0,933 . The total variance explanatory percentage of the scale is 42,906 with a very high reliability level. HRIS-oriented Employee Performance scale consists of 10 items with factor loads ranging from 0,518 to 0,888 . The total variance explanatory percentage of the scale is 37,116 with a very high reliability level. The results of the analysis conducted in order to test the hypotheses using the data collected in the research are presented in the findings section. This section includes distribution of the employees by personal information, and descriptive statistics of the scale scores, and tables and comments on the analysis of the relationship and impact between the scales.

\subsection{Personal Information}

This section provides the distribution of the participating employees by their personal information.

Table 2: Distribution by Personal Information 


\begin{tabular}{|c|c|c|}
\hline & $\mathbf{n}$ & $\%$ \\
\hline \multicolumn{3}{|l|}{ Sex } \\
\hline \multirow{2}{*}{\multicolumn{3}{|c|}{ Age }} \\
\hline & & \\
\hline \multirow{2}{*}{\multicolumn{3}{|c|}{ Educational Status }} \\
\hline & & \\
\hline \multirow{2}{*}{\multicolumn{3}{|c|}{ Period of Employment in the }} \\
\hline & & \\
\hline \\
\hline \multirow{2}{*}{\multicolumn{3}{|c|}{ Position in the Organization }} \\
\hline & & \\
\hline Do you use human resources & & \\
\hline information cyatom in vour & & \\
\hline
\end{tabular}

The table shows the distribution of the employees by personal information in this research conducted to investigate the impact of HRIS usage on organizational efficiency and personal performance in companies. 50,6\% of the participating employees were males with $49,4 \%$ of them being at the ages of $26-30$ and $55,0 \%$ having either master's degree or $\mathrm{PhD}$, and $40,6 \%$ of them have been working in the organization less than 1 year, and $82,5 \%$ work in a first level position.

$90 \%$ of the participating employees stated that their organization uses human resources information system (HRIS).

\subsection{HRIS Usage Status in the Organization}

This section presents the distributions on the usage of HRIS operations in the organizations.

Table 1: Distribution of Usage Status of HRIS in the Organization

\begin{tabular}{|l|c|c|c|c|c|c|}
\hline \multirow{2}{*}{} & \multicolumn{2}{|c|}{ Used } & \multicolumn{2}{c|}{ Not used } & \multicolumn{2}{c|}{ No idea } \\
\cline { 2 - 8 } & $\mathbf{n}$ & $\%$ & $\mathbf{n}$ & $\%$ & $\mathbf{n}$ & $\%$ \\
\hline Record keeping and management & 137 & 85,6 & 0 & 0,0 & 23 & 14,4 \\
\hline Professional development & 42 & 26,3 & 87 & 54,4 & 31 & 19,4 \\
\hline Skill inventory & 32 & 20,0 & 97 & 60,6 & 31 & 19,4 \\
\hline Retirement management & 81 & 50,6 & 49 & 30,6 & 30 & 18,8 \\
\hline
\end{tabular}




\begin{tabular}{|l|c|c|c|c|c|c|}
\hline Discharge management & 104 & 65,0 & 40 & 25,0 & 16 & 10,0 \\
\hline $\begin{array}{l}\text { Equal employment } \\
\text { opportunity/Approval operation }\end{array}$ & 78 & 48,8 & 58 & 36,3 & 24 & 15,0 \\
\hline Job evaluation & 50 & 31,3 & 73 & 45,6 & 37 & 23,1 \\
\hline Time and participation & 51 & 31,9 & 71 & 44,4 & 38 & 23,8 \\
\hline Work health and safety & 99 & 61,9 & 38 & 23,8 & 23 & 14,4 \\
\hline Personnel affairs & 119 & 74,4 & 18 & 11,3 & 23 & 14,4 \\
\hline Salary and payroll operations & 133 & 83,1 & 18 & 11,3 & 9 & 5,6 \\
\hline Human resources planning & 81 & 50,6 & 37 & 23,1 & 42 & 26,3 \\
\hline $\begin{array}{l}\text { Human resources selection and } \\
\text { supply }\end{array}$ & 100 & 62,5 & 18 & 11,3 & 42 & 26,3 \\
\hline Duty assignment & 111 & 69,4 & 40 & 25,0 & 9 & 5,6 \\
\hline Performance appraisal & 110 & 68,8 & 41 & 25,6 & 9 & 5,6 \\
\hline Health and safety & 103 & 64,4 & 41 & 25,6 & 16 & 10,0 \\
\hline Management-employee relations & 70 & 43,8 & 60 & 37,5 & 30 & 18,8 \\
\hline $\begin{array}{l}\text { Human resources training and } \\
\text { development operations }\end{array}$ & 86 & 53,8 & 58 & 36,3 & 16 & 10,0 \\
\hline Wage management & 83,5 & 52 & 32,5 & 24 & 15,0 \\
\hline Career planning & 51,9 & 60 & 37,5 & 17 & 10,6 \\
\hline
\end{tabular}

The research showed that the most-widely used HRIS operations in the organizations are record keeping and management, wage and payroll operations, and personnel affairs, while the least-used operations are skill inventory, professional development, job evaluation, time and participation, and management-employee relations, and equal employment opportunity/approval operation. 
Table 4: Descriptive Statistics of the Scores of HRIS Usage Rate, Organizational Efficiency, Personal Performance and HRIS-oriented Personal Performance

\begin{tabular}{|l|c|c|c|c|c|}
\hline & $\mathbf{n}$ & Minimum & Maximum & $\mathbf{X}$ & SD \\
\hline HRIS Usage Rate & 160 & 0 & 100 & 54,81 & 29,29 \\
\hline Organizational Efficiency & 160 & 14 & 59 & 43,93 & 13,17 \\
\hline Personal Performance & 160 & 15 & 50 & 42,15 & 7,94 \\
\hline $\begin{array}{l}\text { HRIS-oriented Personal } \\
\text { Performance }\end{array}$ & 160 & 9 & 45 & 32,38 & 7,76 \\
\hline
\end{tabular}

The table shows the minimum, maximum, average and standard deviation values of the scores of HRIS Usage Rate, Organizational Efficiency, Personal Performance and HRIS-oriented Personal Performance. Accordingly, HRIS Usage Rate score average is $54,81 \pm 29,29$, and Organizational Efficiency score average is $43,93 \pm 13,17$, and Personal Performance score average is $42,15 \pm 7,94$, and HRIS-oriented Personal Performance score average is $32,38 \pm 7,76$.

4.5. The Results of the Analysis of the Relationship and Impact between HRIS Usage Rate, Organizational Efficiency/Performance, Personal Performance and HRIS-oriented Personal Performance

This section analyzes the level of relationship and impact between scale scores through correlation and regression analysis, and the tables show the results.

Table 5: The Analysis of the Relationship between HRIS Usage Rate, Organizational Efficiency, Personal Performance and HRIS-oriented Personal Performance (Correlation Test)

\begin{tabular}{|l|c|c|c|c|}
\hline & $\begin{array}{c}\text { HRIS } \\
\text { Usage } \\
\text { Rate }\end{array}$ & $\begin{array}{c}\text { Organizational } \\
\text { Efficiency }\end{array}$ & $\begin{array}{c}\text { HRIS- } \\
\text { Performance }\end{array}$ & $\begin{array}{c}\text { oriented } \\
\text { Personal } \\
\text { Performance }\end{array}$ \\
\hline HRIS Usage Rate & 1 &, $634^{*}$ &, $159^{*}$ &, $230^{*}$ \\
\hline Organizational Efficiency & & 1 &, $156^{*}$ &, $406^{*}$ \\
\hline Personal Performance & & & 1 &, $671^{*}$ \\
\hline
\end{tabular}




\section{HRIS-oriented Personal} Performance

${ }^{*} \mathrm{p}<0,05$

The table presents the results of the analysis of the Relationship between HRIS Usage Rate, Organizational Efficiency, Personal Performance and HRIS-oriented Personal Performance. According to these results, there is a positive moderate relationship between HRIS Usage Rate and Organizational Efficiency, and a positive yet quite a weak relationship between HRIS Usage Rate and Personal Performance, and a positive yet a weak relationship between HRIS Usage Rate and HRIS-oriented Personal Performance.

There is a positive yet quite a weak relationship between Organizational Efficiency and Personal Performance, and a positive moderate relationship between Organizational Efficiency and HRIS-oriented Personal Performance.

There is a positive moderate relationship between Personal Efficiency and HRISoriented Personal Performance.

Table 6: The Analysis of the Relationship between HRIS Usage Rate, Personal Performance and HRIS-oriented Personal Performance while Organizational Efficiency being held constant (Partial Correlation)

\begin{tabular}{|l|c|c|c|}
\hline $\begin{array}{l}\text { Constant Variable: } \\
\text { Organizational Efficiency }\end{array}$ & $\begin{array}{c}\text { HRIS Usage } \\
\text { Rate }\end{array}$ & $\begin{array}{c}\text { Personal } \\
\text { Performance }\end{array}$ & $\begin{array}{c}\text { HRIS-oriented } \\
\text { Personal } \\
\text { Performance }\end{array}$ \\
\hline HRIS Usage Rate & 1,000 &, 078 &,- 038 \\
\hline Personal Performance & & 1,000 &, $672^{*}$ \\
\hline $\begin{array}{l}\text { HRIS-oriented Personal } \\
\text { Performance }\end{array}$ & & & 1,000 \\
\hline
\end{tabular}

${ }^{*} p<0,05$

The table shows the results of the analysis of the Relationship between HRIS Usage Rate, Personal Performance and HRIS-oriented Personal Performance while organizational efficiency being held constant. Accordingly, organizational efficiency being constant, there is no statistically significant relationship between HRIS Usage Rate and HRIS-oriented Personal Performance, and between HRIS-oriented Personal Performance and Personal Performance. 
Organizational efficiency being constant, there is a positive moderate relationship between Personal Performance and HRIS-oriented Personal Performance.

Table 7: Analysis of the Impact of HRIS Usage Rate, Personal Performance and HRISoriented Personal Performance on Organizational Efficiency (Regression Analysis)

\begin{tabular}{|c|c|c|c|c|c|c|c|}
\hline $\begin{array}{l}\text { Dependent } \\
\text { Variable }\end{array}$ & Independent Variable & $\mathbf{F}$ & $\mathbf{p}$ & B & $t$ & $\mathbf{p}$ & $\mathbf{R}^{2}$ \\
\hline \multirow{3}{*}{$\begin{array}{l}\text { Organizational } \\
\text { Efficiency }\end{array}$} & HRIS Usage Rate & \multirow{3}{*}{51,765} & \multirow{3}{*}{$0,000^{*}$} & ,257 & 9,822 &, $000 *$ & \multirow{3}{*}{0,499} \\
\hline & Personal Performance & & &,- 356 & $-2,811$ &, $006^{*}$ & \\
\hline & $\begin{array}{l}\text { HRIS-oriented Personal } \\
\text { Performance }\end{array}$ & & & ,709 & 5,391 &, $000^{\star}$ & \\
\hline
\end{tabular}

${ }^{*} \mathrm{p}<0,05$

The results of regression analysis conducted in order to see the impact of HRIS Usage Rate, Personal Performance and HRIS-oriented Personal Performance on Organizational Efficiency are presented in the table. The results show that the regression model is statistically significant $(p<0,05)$.

Looking at the coefficients of HRIS Usage Rate, Personal Performance and HRISoriented Personal Performance, HRIS Usage Rate appears to affect Organizational Efficiency positively $(B=0,257 ; p<0,05)$, whereas it affects Personal Performance negatively $(B=-0,356 ; p<0,05)$, and HRIS-oriented Personal Performance positively $(B=0,709 ; p<0,05)$.

According to the analysis results, the model has an explanatory rate of $50 \%$, and HRIS-oriented Personal Performance has the biggest impact on Organizational Efficiency.

Table 8: Analysis of the Impact of HRIS Usage Rate, Organizational Efficiency and HRIS-oriented Personal Performance on Personal Performance (Regression Analysis)

\begin{tabular}{|c|c|c|c|c|c|c|c|}
\hline $\begin{array}{l}\text { Dependent } \\
\text { Variable }\end{array}$ & Independent Variable & $\mathbf{F}$ & $\mathbf{p}$ & B & $\mathbf{t}$ & $\mathbf{p}$ & $\mathbf{R 2}$ \\
\hline \multirow{3}{*}{$\begin{array}{l}\text { Personal } \\
\text { Performance }\end{array}$} & HRIS Usage Rate & \multirow{3}{*}{47,266} & \multirow{3}{*}{$0,000^{*}$} & ,036 & 1,770 & ,079 & \multirow{3}{*}{0,476} \\
\hline & Organizational Efficiency & & &,- 135 & $-2,811$ &, $006^{\star}$ & \\
\hline & $\begin{array}{l}\text { HRIS-oriented Personal } \\
\text { Performance }\end{array}$ & & & ,748 & 11,522 &, $000^{\star}$ & \\
\hline
\end{tabular}

${ }^{*} p<0,05$ 
The table presents the results of regression analysis conducted in order to see the impact of HRIS Usage Rate, Organizational Efficiency and HRIS-oriented Personal Performance on Personal Performance. The results show that the regression model is statistically significant $(p<0,05)$.

Analyzing the coefficients of HRIS Usage Rate, Organizational Efficiency and HRIS-oriented Personal Performance, it was found that Organizational Efficiency affects Personal Performance negatively $(B=-0,135 ; p<0,05)$, whereas HRIS-oriented Personal Performance affects it positively $(B=0,748 ; p<0,05)$.

The results of the analysis show that the model has an explanatory rate of $48 \%$, and HRIS-oriented Personal Performance has the biggest impact on Personal Performance.

\section{CONCLUSION AND RECOMMENDATIONS}

The research shows that there is a positive relationship between HRIS Usage Rate, and Organizational Efficiency, Personal Performance and HRIS-oriented Personal Performance in the organizations. Accordingly, the following hypotheses of the research are accepted: "H11: There is a relationship between HRIS usage rate and organizational efficiency," "H12: There is a relationship between HRIS usage rate and personal performance," "H13: There is a relationship between HRIS usage rate and HRIS-oriented Personal Performance."

A positive relationship exists between Organizational Efficiency, and Personal Performance and HRIS-oriented Personal Performance. Thus, the following hypotheses of the research are accepted: "H14: There is a relationship between Organizational Efficiency and Personal Performance," "H15: There is a relationship between Organizational Efficiency and HRIS-oriented Personal Performance."

There is also a positive relationship between Personal Performance and HRISoriented Personal Performance. According to this finding, the hypothesis "H16: There is a relationship between Personal Performance and HRIS-oriented Personal Performance" is accepted.

Organizational Efficiency being constant, there is no relationship between HRIS Usage Rate, and Personal Performance and HRIS-oriented Personal Performance. Therefore, the following hypotheses are rejected: "H17: Organizational Efficiency being constant, there is a relationship between HRIS Usage Rate and Personal Performance," "H18: Organizational Efficiency being constant, there is a relationship between HRIS Usage Rate and HRIS-oriented Personal Performance."

Organizational Efficiency being constant, there is a positive relationship between Personal Performance and HRIS-oriented Personal Performance. Consequently, the hypothesis "H19: Organizational Efficiency being constant, there is relationship between personal performance and HRIS-oriented personal performance" is accepted.

Organizational Efficiency affects HRIS Usage Rate and HRIS-oriented Personal Performance positively, while affecting Personal Performance negatively. Accordingly, 
the following hypotheses are accepted: "H110: HRIS Usage Rate affects Organizational Efficiency," "H111: Personal Performance affects Organizational Efficiency," and "H112: HRIS-oriented Personal Performance affects Organizational Efficiency."

HRIS Usage Rate does not affect Personal Performance, but Organizational Efficiency affects Personal Performance negatively, and HRIS-oriented Personal Performance affects Personal Performance positively. Thus, while the hypothesis "H113: HRIS Usage Rate affects Personal Performance" is rejected, the hypotheses "H114: Organizational Efficiency affects Personal Performance," and "H115: HRISoriented Personal Performance affects Personal Performance" are accepted.

Today, we have to work, socialize, bring up children and get retired in the cyber universe created by the digital revolution which occupied the whole world. In order not to be like a vessel in the middle of the sea trying to find its course without the help of electronic and classical navigation tools, the organizations have to formulate a systematic structure and be prepared in order to understand the process of change.

The technology has revolutionized the way we do things, and it keeps doing so through several developments such as internet, social media, big data, internet of things (loT) and artificial intelligence. Depending on these developments, the use of information and communication technologies has spread to every field, and almost become a part of our work and social life by occupying more space. This change dramatically makes its presence felt particularly on the grounds of individual and human resources which are basic elements of the social and organizational structure. The efficient use and role of MIS and HRIS have grown in the businesses, and the information produced by these systems emerged as a strategic factor, and also played a significant role in improvement of the services. The questionnaires handed out generally showed a level of acknowledgment regarding the system quality, information quality, practicality and user-friendliness. HRIS success which is an empirical evidence was affected by HRIS satisfaction, and this satisfaction was also affected by perceived HRIS system quality, perceived HRIS information quality, perceived HRIS userfriendliness and perceived HRIS practicality. The results of the present study demonstrated a high and significant relationship between perceived HRIS information quality and HRIS satisfaction. It also found that information quality is crucial for general Information System success. The results show that HRIS information quality renders HRIS more valuable to the users by providing up-to-date, complete, detailed and easily comprehensible information related with their works to help them in their decisions. Consequently, the results indicate the potentials and competencies of the information systems and show that they play an undeniable role, and employees provide the desired approval to keep up with the technological developments but they do so, primarily, in a way avoiding to do harm to the safety of their careers.

Nevertheless, the advantages of HRIS will not appear if it is not implemented effectively, otherwise they can be obtained haphazardly in an organization, and thus it renders the investment unprofitable and open to question. Conversely, providing a valuable and long-term investment for an organization would only be possible when 
HRIS successfully affects all dimensions of the work environment in an integrated and holistic way.

A successful HRIS should support planning and implementation of basic managerial processes in an organization such as decision-making, technology selection and organizational reporting. Thus, the new HRIS has been an active tool in helping employees to interact more easily among themselves and with their organizations and thereby has added to their productivity and work performance.

The multiple impacts of HRIS on organizational efficiency and performance highlight the need to provide implementation of an effective HRIS. In order to ensure HRIS' positive impact on HR functions, the system has to be harmonized with all basic HR functions such as performance management and reward selection. The impact of HRIS on cost management can be enhanced by assigning a supervising user in each department and offering training for the use of the system in order to provide guidance to the employees with a view to achieving an effective use of the system. All HR function must be implemented sequentially in order to ensure availability of historical data on a central drive and to provide a full return on investments made in HRIS. In order to create a positive impact on time management, the system must be user-friendly, and easy to navigate inside, and must meet the needs of all HR functions. The management satisfaction with the system can be boosted by ensuring information sharing in the course of providing the availability of all contact information of HR in the system, and effective management of all HR functions, and having an indication panel function feature to display high level summary information, and making effective decisions on strategic level and achieving organizational goals in short term. Undoubtedly, an effective and well-implemented HRIS can provide an effective and nearly right strategic direction for the businesses in the big data age of cyber universe, and a work for intellectual capital factor in an effective, reliable and prestigious business environment, and it can support business strategy, and can have the potential of actualizing corporate strategies effectively.

As an open system, an organization is in mutual interaction with the internal and external environment which tries to reach certain equilibrium. Due to the complicated problems created by the effects of rapid changes in the organizational and environmental parameters, human resources are carried to a strategic level since these problems would affect human resources, existing in all levels, and their management process. The best solution would be establishing and constantly developing the information infrastructure as a means to ensure efficiency of HR management in order to manage the change smoothly.

In conclusion, it is inescapable to establish an organizational environment and atmosphere where the employees can freely express themselves and take part in social activities, and where a just and calibrated scale of justice is fully present in all processes and operations of the business, and where uninterrupted communication exists. It can be said that ensuring employees' efficiency at work in the long term and stressful posts without losing their enthusiasm and keeping their loyalty to the organization is possible 
in the organizations which are equipped with a HRIS integrated into the management information system and human resources that would use the system efficiently.

Apart from these data, the research involves some limitations. Firstly, the sample employed in the research poses a limitation. Moreover, conducting the research on a sample, i.e. cross-sectional data, located in a certain region can be considered a limitation. Repeating a similar model in future research in a larger sample selected from the regions governed by different environmental conditions using long-term research data would provide a better understanding of the relationships between the variables.

\section{REFERENCES}

AKALIN, M. M. (1992). Kamu İktisadi Teşebbüslerinde Örgütsel Etkinlik ve Toprak Mahsulleri Ofisi Genel Müdürlügü̈nde Bir Uygulama, Unpublished Master's Thesis, Gazi Üniversitesi Sosyal Bilimler Enstitüsü, Ankara.

AKMAN, V., (2010), Insan Kaynakları Bilgi Sistemleri Sakarya Ilinde bir araştırma, Unpublished Master's Thesis, Sakarya Üniversitesi, Sakarya.

AMMARHUSEIN, (2015). The Employee Perception of the Human Resources Information Systems Success, International Journal Of Business and Management Invention, 4(2): 10-15, http://www.ijbmi.org/papers/Vol(4)2/Version-2/B0422010015.pdf, Access Time: 17.11.2015.

ALDEMIR, C., ATAOL, A. and BUDAK, G. (2004). Insan Kaynakları Yönetimi, Barış Yayınları, İzmir.

ARAS, M. (2012). Insan Kaynakları Bilgi Sistemlerinin Başarısında Rol Oynayan Faktörler: Bir Araştırma, Unpublished Master's Thesis, Sakarya Üniversitesi, Sakarya.

ARGOTE, L, ve INGRAM, P. (2000). Knowledge Transfer: A Basis for Competitive Advantage in Firms, Organizational Behavior and Human Decision, 82(1):150-169, http://dx.doi.org/10.1006/obhd.2000.2893

BACH S., (2000), From Performance Appraisal to Performance Management, Personnel Management: A Comprehensive Guide to Theory and Practice, Blackwell Business, Oxford.

BAILEY, J. E. and SAMMY W. P, (1983), Development a tool for measuring and analyzing computer user satisfaction, Management Science, 29 (5): 530-545, http://dx.doi.org/10.1287/mnsc.29.5.530

BAYRAKTAROĞLU, S., (2001) Stratejik Insan Kaynakları Yönetimi: Işyerinde Öğrenme Boyutu, 9. Ulusal Yönetim ve Organizasyon Kongresi Bildiriler, I.Ü. İşletme Fakültesi Araştırma ve Yardım Vakfı Yayınları, İstanbul.

BAYRAKTAROĞLU, S., and Tunçbilek, M., (2011), Bilgi Toplumunda Insan Kaynakları Yönetiminin Değişen Yüzü, 1.Ulusal Bilgi, Ekonomi ve Yönetim Kongresi Tebliğleri.

BAYRAKTAROĞLU, S. and YILMAZ, S. E. (2012). İnsan Kaynakları Yönetiminde İş Etiği Uygulamaları İle Örgütsel Performans Arasındaki Iliş̧ki: Fortune Türkiye En Büyük 500 Şirket Örneği, Iş Ahlakı Dergisi, 5(10): 117-148. 
BEADLES-II, N. A., LOWERY, C. M. and JOHNS, K. (2005). The Impact of Human Resource Information Systems: An Exploratory Study in the Public Sector. Journal of Communications of the IIMA, 5(4), 39-46. http://www.iima.org/CIIMA/11\%205.4_Beadles_39-46.pdf

BINGÖL, D. (2010). Insan Kaynakları Yönetimi, Beta Basım Yayım, İstanbul.

BOATENG, A. (2007). The Role of HRIS in SHRM. Masters Thesis. University of Sweden.

BROWN, S. (2008). Human Resource Information Systems. Compare HRIS https://www.comparehris.com/human-resource-information-systems-/ Access Time: 17.11.2015.

BÜLBÜL, H. (2007), Bilgi Yönetim Modellerinin Üretim Ve Firma Performansına Etkisi, Selçuk Üniversitesi $\begin{array}{lllll}\text { Sosyal Bilimler } & \text { Enstitüsü } & \text { Dergisi, } & \text { Vol. }\end{array}$ http://dergisosyalbil.selcuk.edu.tr/susbed/article/view/444/426, Access Time: 17.11.2015.

CLARKE, P. and COOPER, M. (2000). Knowledge Management and Collaboration, Proc. of the Third Int. Conf. On Practical Aspects of Knowledge Management (PAKM2000) Basel, Switzerland, 3031 October 2000. http://ceur-ws.org/Vol-34/clarke_cooper.pdf, Access Time: 21.11.2015.

ÇELIKK. A. and AKGEMCi. T., (2015), Yönetim Bilişim Sistemleri, Gazi Kitabevi, Ankara.

ÇÖL, G. (2008). Algılanan Güçlendirmenin İşgören Performansı Üzerine Etkileri, Doğuş Üniversitesi Dergisi, 9 (1): 35-46. http://journal.dogus.edu.tr/index.php/duj/article/view/77/92, Access Time: 21.11.2015.

ÇAKAR, N. D., YILDIZ, S. and DUR, S. (2010). Bilgi Yönetimi Ve Örgütsel Etkinlik Illişkisi: Örgüt Kültürü Ve Örgüt Yapısının Temel Etkileri, Ege Akademik Bakış / Ege Academic Review 10 (1): 71-93. http://www.onlinedergi.com/MakaleDosyalari/51/PDF2010_1_5.pdf, Access Time: 22.11.2015.

DESSLER, G. (2005) Human Resource Management. 10th ed. Pearson Prentice Hall.

DIANNA L.S., EUGENE F. S.-R. and LUKASZEBSKI K. (2006). Factors Affecting The Acceptance and Effectiveness of e-HRS, USA: Elseiver Inc., DOI: 10.1016/j.hrmr.2006.03.010

DUYGULU, D. (2003). Örgütsel Etkinlik Kriterlerinin Örgütsel Başarımdaki Rolü, İş, Güç Endüstri Illişkileri ve Insan Kaynakları Dergisi, $\quad 5 \quad$ (1), http://www.isgucdergi.org/?p=article\&id=27\&cilt=5\&sayi=1\&yil=2003, Access Time: 12.10.2015.

EKINCI, H. and YILMAZ, A. (2002), Kamu Örgütlerinde Yönetsel Etkinliğin Araştırılması Üzerine Bir Araştırma, Erciyes Üniversitesi Iktisadi ve Idari Bilimler Fakültesi Dergisi, 19 (July-December): 3550, http://iibf.erciyes.edu.tr/dergi/sayi19/03_Ekinci_Yilmaz.pdf, Access Time: 12.10.2015.

FUGATE, B.S., STANK, T.P., and MENTZER, J.T., (2009). Linking Improved Knowledge Management to Operational and Organizational Performance, Journal of Operations Management, 27: 247-264, http://dx.doi.org/10.1016/j.jom.2008.09.003

GIBSON J.L., J.M. IVANCEVICH and J.H. DONNELLY, Jr. (1991), Organizations (Behavior-StructureProcesses), 7th Ed., Irwin Inc.

GOLD, H.A., MALHOTRA, A. and SEGARS, A.H, (2001). Knowledge Management: An Organizational Capabilities Perspective, Journal of Management Information Systems, 18 (1): 185-214, http://www.jstor.org/stable/40398521, Access Time: 18.10.2015. 
GÖKÇEN, H. (2007). Yönetim Bilgi Sistemleri, Palme Yayıncılık, Ankara.

HENRY, K.I., C. PAINTER. and C. BARNES. (1993), Management in The Public Sector (Challenge and Change), Chapman and Hall, London.

HUSSAIN, Z., WALLAGE J., and CORNALIUS N. E. (2007). The Use and Impact of HRIS on Human Resources Management Professionals, Information \& Management, 44 (1): 74-89, http://dx.doi.org/10.1016/j.im.2006.10.006

IVANCEVICH, M, (1990), Organizational Bahavior and Management, BPI/IRWIN, Second Edition, USA.

JOHNSON D.R. and GUEUTAL G.H. (2012). Transforming HR Through Technology The Use of E-HR and HRIS in Organizatios, SHRM Foundation at (703) 535-6020. Online at www.shrm.org/foundation.

KARCIOĞLU, F. and ÖZTÜRK, (2009). İşletmelerde Performans Değerleme ile İnsan Kaynakları Bilgi Sistemleri (IKBS) Arasındaki İlişkisi -İstanbul İlinde Bir Araştırma, Atatürk Üniversitesi Sosyal Bilimler Enstitüsü Dergisi, $13 \quad$ (1): 343-366, http://edergi.atauni.edu.tr/ataunisosbil/article/view/1020002632/1020002626, Access Time: 17.11.2015

KAVANAGH M. J., GUEUTAL H.G., and TANNENBAUM S. I., (1990), Human Resources Information System: Developement and Application, PWS Kent, Asia Pacific Journal of Human Resources, 28(4): 4-144. DOI: 10.1177/103841119002800422

KAYA N., and KESEN M., (2014), İnsan Kaynakları Yönetimi Uygulamaları ve Örgüt Kültürü Tiplerinin Çalışan Performansı Üzerindeki Etkilerini İncelemeye Yönelik Ampirik Bir Çalışma, EKEV Akademi $\begin{array}{llll}\text { Dergisi, } & 58 & \text { (Winter 2014): } & \text { 97-122, }\end{array}$ http://www.ekevakademi.org/Makaleler/1050717640_06\%20Nihat\%20KAYAMustafa\%20KESEN.pdf, Access Time: 17.11.2015

KHERA Sh.N., and KARISHMA G. (2012), Human Resource Information System and its impact on Human Resource Planning, IOSR Journal of Business and Management, 3(6): 6-13, https://pdfs.semanticscholar.org/e274/b0962f6cb54ec9feb95ebb456b1704861bd9.pdf, Access Time: 16.10 .2015

KIRKMAN, B. L., and ROSEN, B. (1999). Beyond Self-Management: Antecedents and Consequences of Team Empowerment. The Academy of Management Journal, 42(1): 58-74, http://dx.doi.org/10.2307/256874

KRISTINE D., GRANT D. and WIBLEN S. (2006), Human Resources Information (HRIS): Replacing or Enhancing HRM, https://www.researchgate.net/publication/228793352, Access Time: 18.10.2015

KUMAR, N. A. and PARUMASUR, S. B. (2013). The Impact of HRIS on Organizational Efficiency.: Random or Integrated and Holistic?, Corporate Ownership \& Control, 11(1): 567-575.

LAWLER, E.E. and MORHMAN S.A. (2003). HR As A Strategic Partner What Does It Take to Make It $\begin{array}{lllll}\text { Happen?, } & \text { Ceo } & \text { Publication } & \text { 03-2 } & \text { (430), }\end{array}$ https://www.researchgate.net/profile/Edward_Lawler/publication/237253681_'HR_as_Strategic_P artner_What_does_it_Take_to_Make_it_Happen'/links/548f15c30cf214269f2635b6.pdf, Access Time: 17.11 .2015 
McEvily, S. K. and CHAKRAVARTHY, B. (2002). The Persistence of Knowledgebased Advantage: an Empirical Test for Product Performance and Technological Knowledge, Strategic Management Journal, 23(4): 285-305, DOI: 10.1002/smj.223

NOWDURI S. (2011). Management İnformation Systems and Business Decision Making: Review, Analysis, and Recommendations, Journal of Management \& Marketing Research, 7(March): 1-8, http://www.aabri.com/manuscripts/10736.pdf, Access Time: 17.11.2015

OGUT, A. (2012). Bilgi Çağında Yönetim, Nobel Yayınları, Ankara.

OGUT, A., AKGEMCi, T. and DEMiRSEL M. T. (2004). Stratejik Insan Kaynakları Yönetimi Bağlamında Örgütlerde İşgören Motivasyonu Süreci, Selçuk Üniversitesi Sosyal Bilimler Enstitüsü Dergisi, Vol. 12, p. 277-290, http://dergisosyalbil.selcuk.edu.tr/susbed/article/view/710/662, Access Time: 18.11.2015

ÖZGEN, H., ÖZTÜRK A. and YALÇIN, A. (2002). Insan Kaynakları Yönetimi, Ankara, Nobel.

PLUNKETT, P. T. (2001), Managing Knowledge \& Work: An Overview of Knowledge Management, Knowledge Management Working Group of the Federal Chief Information Officers Council, August, http://www.providersedge.com/docs/km_articles/KM_at_Work.pdf, Access Time: 18.11.2015

RANGRIZ H., MEHRABI J. and AZADEGAN A., (2011), The Impact of Human Resource Information System on Strategic Decisions in Iran, Computer and Information Science, 4(2): 81-87, http://citeseerx.ist.psu.edu/viewdoc/download?doi=10.1.1.659.4476\&rep=rep1\&type=pdf, Access Time: 18.10.2015

SABUNCUOĞLU, Z. (2000). Insan Kaynakları Yönetimi, Ezgi Kitapevi Yayınları Bursa.

SADIQ U. KHAN A. F., IKHLAQ K. and MUJTABA B. G. (2012), The Impact of Information Systems on the Performance of Human Resources Department, Journal of Business Studies Quarterly, 3(4): 77-91, https://pdfs.semanticscholar.org/6081/94ea035aadab5aaf69555612a114d506ff39.pdf, Access Time: 18.10 .2015

SAĞSAN, M. (2002), Örgütsel Seçimlerde Küme Modeli: İnsan Illişkileri Eko1ü, Bilgi Yönetimi ve Örgütsel Öğrenmenin Ara Kesitinde "Insan", Bilgi Dünyası, 3(4): 205-230, http://elis.da.ulcc.ac.uk/7349/1/205-230.pdf, Access Time: 18.10.2015

SEKARAN, U. (2003). Research Methods for Business: A Skill Building Approach, 4th Edition, John Wiley \& Sons Inc., New York.

SERGIO, B., PEZ, G., SEBASTI, M. and UGARTE, N. (2010). On The Quest of Choosing an Effect HR Information System - Assessing its Role and Key Success Factors. Horizontes Empresariales, 9 (1): 49-54.

SIGLER, T.H., and PEARSON, C. M. (2000). Creating an Empowering Culture: Examining the Relationship Between Organizational Culture and Perceptions of Empowerment. Journal of Quality Management, 5(1): 27-52, http://dx.doi.org/10.1016/S1084-8568(00)00011-0

SIPAHI, B., YURTKORU, E.S. and ÇINKO, M., (2008). Sosyal Bilimlerde SPSS ile Veri Analizi, İstanbul: Beta Yayınları. 
ŞIMŞEK, Ş. and ÇELIK, S., (2015), Iş̧letme Bilimine Giriş, Eğitim Yayınevi, Konya.

ŞiMŞEK, Ş. and ÖGE, S., (2015), Insan Kaynakları Yönetimi, Eğitim Yayınevi, Konya.

TEOTIA, K. (2012). Role of HRIS in Performance Evaluation \& Decision Making, International Journal of Multidisciplinary Research, 2(4), ISSN 22315780.

TORTOP, N., ÖZER, M. A., BURHAN, A. and YAYMAN, H. (2010). Insan Kaynakları Yönetimi, Nobel Yayın Dağıtım, Ankara.

TUTAR H. and ALTINÖZ M. (2010). Örgütsel İklimin İşgören Performansı Üzerine Etkisi: Ostim İmalât İşletmeleri Çalışanları Üzerine Bir Araştırma, Ankara Üniversitesi SBF Dergisi, 65(2): 196-218, DOI: 10.1501/SBFder_0000002162

WIBLEN, S., GRANT, D. and DERY, K. (2010). Transitioning to a New HRIS: The Reshaping of Human Resources and İnformation Technology Trust. Journal of Electronic Commence Research, 11 (4): 251-267, https://www.researchgate.net/publication/228369575_Transitioning_to_a_new_HRIS_The_resha ping_of_human_resources_and_information_technology_talent, Access Time: 15.12. 2015.

YEUNG, A. C. L., LAI, K., and YEE, R. W. (2007). Organizational Learning, Innovativeness, and Organizational Performance: A Qualitative Investigation, International Journal of Production Research, 45(11): 2459-2477, http://dx.doi.org/10.1080/00207540601020460

YILDIZ, O., DAĞDEVIREN, M. and ÇETINYOKUŞ, T. (2008). İşgören Performansının Değerlendirilmesi İçin Bir Karar Destek Sistemi ve Uygulaması, Gazi Üniv. Müh. Mim. Fak. Der. J. Fac. Eng. Arch. Gazi Univ., 23(1): 239-248, http://www.mmfdergi.gazi.edu.tr/article/viewFile/1061000220/1061000191, Access Time: 15.12. 2015. 